\title{
Environmental, technical and technological aspects of hazardous waste management in Poland
}

\author{
Justyna Pyssa ${ }^{1, *}$ \\ ${ }^{1}$ AGH University of Science and Technology, Faculty of Energy and Fuel, Al. Mickiewicza 30, 30-059 Cracow, Poland
}

\begin{abstract}
The issue of recovery and disposal of hazardous waste is not a new concern. The waste comes from various processes and technologies and therefore the bigger emphasis should be placed on reducing quantities of generated hazardous waste (which is often connected with changes in the technology of manufacturing a given product) and limitation of their negative influence on natural environment. Plants specializing in waste processing processes should meet the so-called cardinal triad of conditions deciding on the full success of investment, and namely: economic effectiveness, ecological efficiency and social acceptance. The structure of generation of hazardous waste in EU-28 has been presented in the paper. Methods of hazardous waste disposal in Poland have been discussed. Economic and ecological criteria for the selection of technology of hazardous waste disposal have been analyzed. The influence of the hazardous waste on the environment is also presented. For four groups of waste, which are currently stored, alternative methods of disposal have been proposed.
\end{abstract}

\section{Introduction}

It was nearly till the end of the 70 's of the previous century that the storage was the most commonly used and legally accepted method of waste disposal in Poland. The policy conducted in such manner, in which the emphasis was placed first of all on the increase of production capacity and not on ecological effects, contributed to the devastation of natural environment. For that reason actions were taken aimed not only at changes in legislation, but also in mentality and ecological awareness of the society. The idea of sustainable development started to penetrate the ecological politics of countries implying that criteria of sustainability would gain a position equivalent to economic criteria.

Currently the primary objective of natural environment protection is not so much the control of degree of environmental pollution and waste disposal, but the prevention of their generation.

\section{Hazardous waste in the EU and Poland}

Hazardous waste is generated in all sectors of the economy. The structure of produced waste results from the industrial specificity of a given country. In all of the European Union (EU-28) a total of 95.02 million $\mathrm{Mg}$ of hazardous waste was generated in 2014 [1]. In comparison with 2012 , the quantity decreased by 5.67 percent. The largest decreases in the amount of produced hazardous waste one can observe in Ireland, Belgium, the United Kingdom and Bulgaria. The biggest increases in the number of generated hazardous waste one can see in Cyprus, Denmark, Estonia and Finland. In Fig. 1 the structure of production of hazardous waste in countries of the European Union (EU-28) in the years 2010 to 2014 is presented.

Changes in the quantity and quality of generated hazardous waste depend on the development of particular industry branches. In Poland in the year 2014 $1,876,577 \mathrm{Mg}$ of hazardous waste was produced. The largest part of hazardous waste underwent the processes of recovery other than the energy recovery and except backfilling - 1,492,430 Mg - which comprises 79.53 percent. Another process in terms of the quantity of managed waste is the deposit onto or into land $-244,786$ $\mathrm{Mg}(13.04 \%) .135,443 \mathrm{Mg}$ (7.22\%) of hazardous waste underwent the process of incineration/disposal (D10). $2,492 \mathrm{Mg}(0.13 \%)$ of hazardous waste underwent the processes of incineration and energy recovery (R1), while the land treatment and release into water bodies were applied to $1,426 \mathrm{Mg}(0.08 \%)$ of produced hazardous waste. In Fig. 2 the percentage of particular manners of managing hazardous waste in Poland is illustrated.

\section{Methods of waste disposal}

Before making the decision as the choice of technology of disposal of a given group of waste it is necessary to familiarize oneself with many issues of both legal and technical and economic nature. In the majority of countries legal provisions have been introduced which precisely define processes connected with sourcing, storage, transportation and technologies of treatment of given groups of waste. The knowledge in this area is provided by directives of the European Union and

\footnotetext{
* Corresponding author: jpyssa@agh.edu.pl
} 


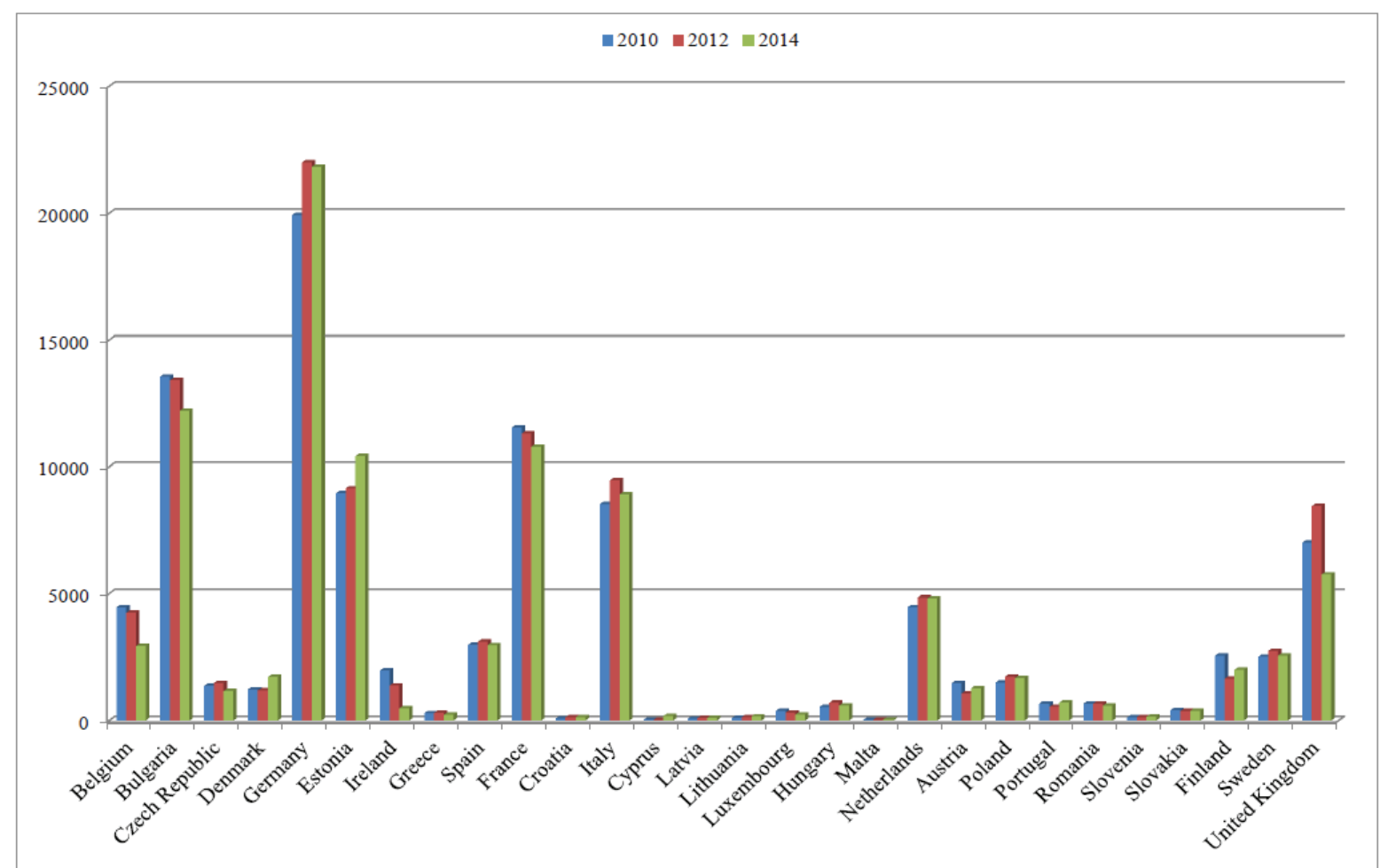

Fig. 1. Structure of production of hazardous waste in EU-28 in the years 2010 to 2014 (author's own research based on [1]).

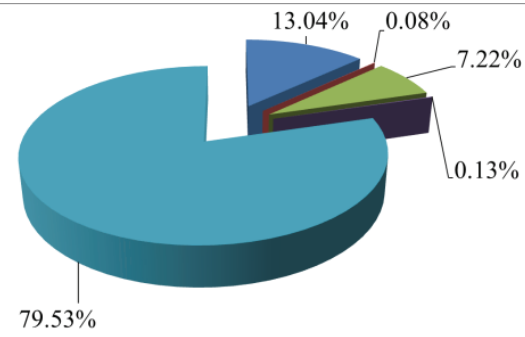

Deposit onto or into land

- Land treatment and release into water bodies

Incineration/disposal (D10)

- Incineration/energy recovery (R1)

Recovery other than energy recovery - except backfilling

Fig. 2. Proceeding with hazardous waste generated in Poland in 2014 (author's own research based on [1]).

provided by directives of the European Union and changes in legal provisions of the Polish law.

The manner of waste disposal is selected according to properties of substances which are going to be the subject for the process. There are no universal methods thanks to which all and any waste can be disposed. This is why the selective collection of hazardous waste is so important [2]. The division of technologies of hazardous waste disposal is presented in the Table 1.

In the classification of hazardous waste disposal technologies one adopts the rule of grouping wastes according to their properties and possibilities of disposal. Depending on the chemical composition waste can be disposed in identical conditions. In Table 2 there is a comparison of particular groups of hazardous waste along with applied methods of its disposal. The choice of optimal technology of economicutilization, disposal and storage depends on many factors [2-5], and namely:
Table 1. Technologies of disposal/recovery of waste.

\begin{tabular}{|c|c|}
\hline Method of disposal/recovery & Description \\
\hline Physico-chemical & $\begin{array}{l}\text { The aim is the } \\
\text { transformation of hazardous } \\
\text { waste to such a state which } \\
\text { will allow for final disposal } \\
\text { non-burdensome to the } \\
\text { environment through energy } \\
\text { and raw material utilization } \\
\text { or which will allow safe } \\
\text { storage as an alternative }\end{array}$ \\
\hline Biological & $\begin{array}{l}\text { It applies to organic waste } \\
\text { and the aim is the } \\
\text { improvement of agricultural } \\
\text { condition of farmlands } \\
\text { (natural circulation of } \\
\text { elements in nature) }\end{array}$ \\
\hline Thermal & $\begin{array}{l}\text { The aim is the energy } \\
\text { recovery and reduction of } \\
\text { the mass of waste - energy } \\
\text { recycling }\end{array}$ \\
\hline $\begin{array}{l}\text { Transformation of waste into } \\
\text { form of primary and } \\
\text { secondary raw materials }\end{array}$ & $\begin{array}{l}\text { It leads to saving in natural } \\
\text { resources and energy } \\
\text { (material recycling) }\end{array}$ \\
\hline $\begin{array}{l}\text { Depositing waste on ordered } \\
\text { landfills }\end{array}$ & $\begin{array}{l}\text { Final way of managing } \\
\text { residual waste further } \\
\text { disposal of which is not } \\
\text { justified either in technical } \\
\text { and economic terms }\end{array}$ \\
\hline
\end{tabular}

- characteristics of waste (physical, chemical and technological properties, raw material composition, nuisance to the environment),

- quantity of waste deciding about the capacity of facilities (absorbability of landfills, efficiency 
Table 2. Methods of disposal of hazardous waste (author's own research based on [3]).

\begin{tabular}{|c|c|c|c|c|c|}
\hline Type of waste & Recovery & Incineration & $\begin{array}{c}\text { Physico-chemical } \\
\text { or biological } \\
\text { treatment }\end{array}$ & Solidification & Land forming \\
\hline $\begin{array}{l}\text { Liquid waste similar to } \\
\text { sewage }\end{array}$ & & & $\mathrm{X}$ & & \\
\hline $\begin{array}{l}\text { Waste containing acids and } \\
\text { alkalis }\end{array}$ & & & $\mathrm{X}$ & & \\
\hline $\begin{array}{lll}\text { Waste containing heavy } \\
\text { metals }\end{array}$ & & & $\mathrm{X}$ & $\mathrm{X}$ & $\begin{array}{l}\text { After chemical } \\
\text { fixation }\end{array}$ \\
\hline $\begin{array}{l}\text { Waste containing inorganic } \\
\text { toxic chemical compounds }\end{array}$ & & & $\mathrm{X}$ & $\mathrm{X}$ & $\begin{array}{l}\text { After chemical } \\
\text { neutralization }\end{array}$ \\
\hline $\begin{array}{l}\text { Waste of high chemical } \\
\text { reactivity }\end{array}$ & & & $\mathrm{X}$ & & \\
\hline $\begin{array}{l}\text { Waste containing neutral } \\
\text { inorganic substances }\end{array}$ & $\mathrm{X}$ & & & & \\
\hline Used oils and solvents & $\mathrm{X}$ & $\mathrm{X}$ & & & \\
\hline $\begin{array}{l}\text { Used resins, paints, } \\
\text { solvents, glues }\end{array}$ & $\mathrm{X}$ & $\mathrm{X}$ & & & \\
\hline $\begin{array}{l}\text { Waste containing organic } \\
\text { chemical substances }\end{array}$ & $\mathrm{X}$ & $\mathrm{X}$ & $\mathrm{X}$ & & \\
\hline $\begin{array}{l}\text { Out-dated plant protection } \\
\text { products }\end{array}$ & & $\mathrm{X}$ & $\mathrm{X}$ & & \\
\hline $\begin{array}{ll}\text { PCBs, } & \text { chlorinated } \\
\text { hydrocarbons } & \\
\end{array}$ & & $\mathrm{X}$ & & & \\
\hline $\begin{array}{l}\text { Waste containing organic } \\
\text { biodegradable substances }\end{array}$ & & $\mathrm{X}$ & $\mathrm{X}$ & & \\
\hline
\end{tabular}

of installations for commercial exploitation waste disposal), frequency of waste generation and spatial distribution of sources of formation,

- possibility of continuous reception of products which emerged during the treatment of waste such as secondary raw materials, compost and waste heat,

- field conditions such as: availability of sites for building, location of facilities, hydro-geological conditions of the surface, meteorological conditions, preserving protection zone, influence of waste on ground waters, soil and air,

- technical (availability of proven technologies) and financial (investment and operating costs) possibilities of execution of construction of facilities,

- social acceptance for the location and proposed solutions.

Plants, in which hazardous waste is treated, must fulfill three essential conditions which are: economic efficiency, environmental efficiency and social acceptance. As far as the ecological factor is indisputable, two remaining elements of the balance configuration are burdened with strong financial and social interaction. This is the result of- among others high investment costs and the phenomenon described in the literature as the 'NIMBY' (not in my backyard) syndrome $[2,6]$.

In Fig. 3 existing installations of hazardous waste recovery and disposal in Poland are indicated. The biggest number of installations is present in southern Poland (voivodships: silesian (24), malopolska (17) and opolskie (8)). In central Poland most of facilities are located in masovian (9), lodzkie (9) and kujawskopomorskie (7) voivodships. And in the north of Poland the number is 11 . It is connected with the location of industrial plants producing hazardous waste in those voivodships.

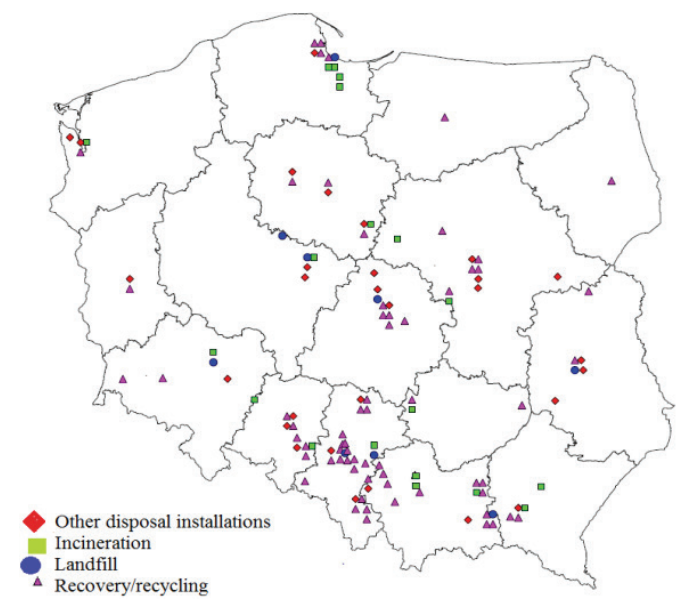

Fig. 3. Location of installations of hazardous waste recovery and disposal in Poland [8].

\section{Conditions of waste management}

Recovery of raw materials from waste, waste disposal as well as storage requires not only proper technologies, but expensive installations and equipment first of all. One also cannot forget about costs related with temporary warehousing, transportation and loading. Additionally an important factor to which the attention should be drawn is burdening the environment with by-products (sewage, waste gases, secondary waste). Building of new facilities for waste management enables the introduction of modern technologies and ensures the environment protection at a proper level. This is why it is so important 
to familiarize oneself with the structure of hazardous waste generation in a given area and application of optimal organizational and technological solutions codified in a form of BAT-Best Available Techniques [6].

\subsection{Environmental conditions}

Inconsistent waste management is an indication of the ineffective utilization of resources in terms of the environment protection. Incorrect waste management affects all components of the environment, including the state of ecosystems and the health and living quality of people. Highly-consumptive lifestyle and industry development has influence on generating huge quantities of waste, hazardous waste in particular. All investments in the area of waste management - regardless of nature, scale and functions they are supposed to perform in the future - influence the environment. The direct or indirect effect can be building and construction work, exploitation of newly-created and modernized facilities and installations as well as processes occurring in them.

Properly designed facilities of hazardous waste management reduce the pressure onto the environment which has influence on the improvement of quality of abiotic atmospheric components (air status/quality, water and soil quality). It has a positive impact on biological diversity of a region and proper functioning of ecosystems.

Both in the phase of investment realization and later exploitation interactions connected with the emission of noise, dust and air pollution emerge. The emissions depend on the sort of waste treated, applied technology and processes and location characteristics of a given facility. The exploitation of waste management facilities such as incineration plants, waste treatment plants, recycling plants and landfills result in emergence of secondary waste apart from typical contaminants that is dust and gaseous substance emission, thermal energy, radiation, noise and odor emission and discharge of pollutants into the water. It is therefore necessary to seek such technologies which, in addition to being very efficient in removing hazardous waste, will emit low volumes of secondary pollutants.

In general, the majority of waste treatment plants cause the emission of carbon dioxide, ammonia and volatile organic compounds. Other polluting chemical compounds are hydrogen chloride, hydrogen sulphide and dioxins.

In Table 3 processes of waste treatment along with accompanying emissions into the atmosphere are compared.

Another by-product/by-effect from the activity of hazardous waste treatment plants is contaminated sewage. The main components causing pollution are heavy metals, chloro-organic compounds and nitrogenand phosphorus-compounds.

In Table 4 the main processes of waste treatment along with generated contaminants, introduced to the water, are compared.
Table 3. Major contamination emitted as a result of hazardous waste treatment (author's own research based on $[2,8]$ ).

\begin{tabular}{|c|c|}
\hline Process & Chemical compound \\
\hline Biological processes & $\begin{array}{ll}\text { - } & \text { Carbon oxides } \\
\text { - } & \text { Nitrogen oxides }\left(\mathrm{N}_{2} \mathrm{O} \text {, }\right. \\
\left.\mathrm{NO}, \mathrm{NO}_{2}\right) & \\
\text { - } & \text { Volatile organic } \\
\text { - } & \text { Ampounds } \\
\text { - } & \text { Microbial contaminants } \\
\end{array}$ \\
\hline Physico-chemical processes & $\begin{array}{ll}- & \text { Acids (HCL, HF i.a.) } \\
& \text { Ammonia } \\
\end{array}$ \\
\hline Energy treatment of waste & $\begin{array}{ll}\text { - } & \text { Carbon oxides } \\
\text { - } & \text { Sulphur oxides } \\
\text { - } & \text { Nitrogen oxides } \quad\left(\mathrm{N}_{2} \mathrm{O},\right. \\
\left.\mathrm{NO}, \mathrm{NO}_{2}\right) & \\
\text { - } & \text { Volatile organic } \\
\text { compounds pollutants } \\
\text { Particulate } \\
\text { (include metals) }\end{array}$ \\
\hline Incineration & 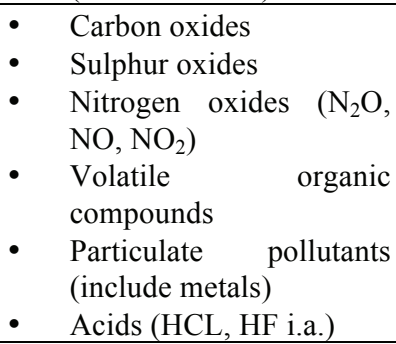 \\
\hline Storage and landfilling & $\begin{array}{ll}\text { - } & \text { Particulate pollutants } \\
\text { (include metals) }\end{array}$ \\
\hline Treatment of waste oils & $\begin{array}{lll} & \begin{array}{l}\text { Volatile } \\
\text { compounds }\end{array} & \text { organic } \\
\end{array}$ \\
\hline Treatment of solvents & $\begin{array}{lll}\text { - } & \begin{array}{l}\text { Volatile } \\
\text { compounds }\end{array} & \text { organic } \\
\end{array}$ \\
\hline $\begin{array}{l}\text { Processes of separation of } \\
\text { water contaminated with } \\
\text { hydrocarbons }\end{array}$ & $\begin{array}{ll} & \text { Volatile } \\
& \text { compounds }\end{array}$ \\
\hline $\begin{array}{l}\text { Storage and warehousing of } \\
\text { organic substances }\end{array}$ & $\begin{array}{l}\text { - } \begin{array}{l}\text { Volatile organic } \\
\text { compounds }\end{array} \\
\end{array}$ \\
\hline
\end{tabular}

Table 4. Main contaminants of water resulting from treatment of hazardous waste (author's own research based on $[2,8]$.

\begin{tabular}{|l|l|}
\hline Process & Chemical compound \\
\hline Biological processes & $\begin{array}{l}\text { Phosphorus; Nitrogen; } \\
\text { Metals (e.g. As, Cd, Cu, Hg, } \\
\text { Ni, Sn, Zn) }\end{array}$ \\
\hline Physico-chemical processes & $\begin{array}{l}\text { Phosphorus; Nitrogen; } \\
\text { Metals (e.g. As, Cd, Cu, Hg, } \\
\text { Ni, Sn, Zn) }\end{array}$ \\
\hline Energy treatment of waste & $\begin{array}{l}\text { Organic compounds (benzene, } \\
\text { toluene, ethylbenzene, xylene, } \\
\text { phenol) }\end{array}$ \\
\hline Treatment of solvents & $\begin{array}{l}\text { Chlorinated aromatic } \\
\text { hydrocarbons; Organic } \\
\text { compounds (benzene, toluene, } \\
\text { ethylbenzene, xylene, phenol) }\end{array}$ \\
\hline Treatment of waste oils & $\begin{array}{l}\text { Metals (e.g. As, Cd, Cu, Hg, } \\
\text { Ni, Sn, Zn); Organic } \\
\text { compounds (benzene, toluene, } \\
\text { ethylbenzene, xylene, phenol) }\end{array}$ \\
\hline Storage and landfilling & $\begin{array}{l}\text { Metals (e.g. As, Cd, Cu, Hg, } \\
\text { Ni, Sn, Zn) }\end{array}$ \\
\hline
\end{tabular}




\subsection{Economic conditions}

Total investment costs of facilities depend on their capacities, location and technical solutions. Costs of facilities increase along with the capacity growth, whereas capital intensity indicator, unit exploitation cost and economic efficiency indicator decrease [2, 5].

Because of high investment costs it is necessary to prepare a detailed analysis of a group of waste produced in a region before making a decision as to the building of a plant treating and disposing hazardous waste. Such analysis should take into account first of all the waste which will be generated in a given region in a longer time perspective. It may turn out repeatedly that it is cheaper to store the waste and then transport it to existing installations instead of building a waste treatment plant.

In Table 5 unit costs of processes of recovery/ disposal of particular types of hazardous waste are compared.

Table 5. Unit costs of processes of recovery/disposal of hazardous waste (author's own research based on [9] .

\begin{tabular}{|l|c|}
\hline Method of recovery/disposal & $\begin{array}{c}\text { Cost of recovery/disposal } \\
\text { PLN/Mg }\end{array}$ \\
\hline Thermal disposal & 3,050 \\
\hline Immobilization in concrete & 1,220 \\
\hline Individual processes & 12,200 \\
\hline Separation of emulsion & 366 \\
\hline $\begin{array}{l}\text { Utilization in industrial } \\
\text { processes }\end{array}$ & 488 \\
\hline Chemical sewage treatment & 976 \\
\hline Physico-chemical treatment & 2,440 \\
\hline $\begin{array}{l}\text { Disposal of waste from } \\
\text { explosives }\end{array}$ & 976 \\
\hline $\begin{array}{l}\text { Storage until development } \\
\text { of technologies }\end{array}$ & $345.2-2,761.3$ \\
\hline $\begin{array}{l}\text { Storage in landfills for } \\
\text { hazardous waste/secure } \\
\text { chemical landfill }\end{array}$ & $170.3-732$ \\
\hline Storage of asbestos & 4,880 \\
\hline Recovery of mercury & 610 \\
\hline Recovery of solvents & \\
\hline Recovery of metals & \\
\hline
\end{tabular}

The given values have been calculated from the original data (stated in PLN for the year 2002) with the use of GDP Deflator (annual percent) Poland 1991-2016 (The United Nations Industrial Commodity Statistics Database). The year 2015 has been adopted as the reference year.

Within certain groups of waste one can note very significant differences in unit costs of disposal/recovery. It arises undoubtedly from the fact that waste treatment plants are of different sizes which is directly connected with their capacities (the more waste treated, the lower unit costs). The cost of waste treatment is associated directly with the cost of storage and delivery to the treatment plant. The price is often the result of individual agreements between a waste-generating facility and waste disposal plant and can be different for various producers.

\subsection{Technical and technological conditions}

Recovery of raw materials from waste, waste disposal and storage require expensive installations, equipment and proper technologies. It involves costs related with waste transportation and reloading as well as investment and operating costs for facilities [10]. One should not also forget about burden to the environment through byproducts such as sewage, waste gases and others [11, 12]. Nevertheless, building of new facilities for waste management enables the introduction of modern technologies and ensures the environment protection at a proper level. This is why it is so important to familiarize oneself with the structure of hazardous waste generation in a given area and application of optimal organizational and technological solutions codified in a form of BAT Best Available Techniques.

Table 6 illustrates the division of used and proven technologies of hazardous waste disposal.

Table 6. Division of methods of disposal of hazardous waste taking account groups of disposed waste [11].

\begin{tabular}{|c|c|c|}
\hline Method & $\begin{array}{l}\text { Group of } \\
\text { waste }\end{array}$ & Application \\
\hline Thermal & $\begin{array}{l}02,03,04, \\
05,07,08, \\
10,12,13, \\
14,16,18, \\
20\end{array}$ & $\begin{array}{l}\text { In general thermal methods are } \\
\text { applied where there is a } \\
\text { possibility of mineralization of } \\
\text { dangerous organic substances } \\
\text { included in waste. Thermal } \\
\text { decomposition can take place in } \\
\text { classic chamber furnaces } \\
\text { (containing special barriers } \\
\text { causing turbulences), rotary } \\
\text { kilns, fluid chambers and plasma } \\
\text { furnaces [10]. Many methods of } \\
\text { thermal utilization of dangerous } \\
\text { waste consists in its total } \\
\text { incineration together with other } \\
\text { fuels and use of energy in } \\
\text { processes of production, for } \\
\text { example cement. In order for a } \\
\text { given installation to be suitable } \\
\text { for dangerous waste disposal, it } \\
\text { must meet specific technical } \\
\text { conditions determined in relevant } \\
\text { regulations. The regulations } \\
\text { define limit values for the } \\
\text { temperature, oxygen content, } \\
\text { time for maintaining exhaust } \\
\text { gases in the incineration chamber } \\
\text { [13]. }\end{array}$ \\
\hline Biological & $\begin{array}{l}02,05,06, \\
07,08,11, \\
12,13,16, \\
17,18,19\end{array}$ & $\begin{array}{l}\text { Biological methods are generally } \\
\text { used for cleaning of plant } \\
\text { protection products, heavy metals } \\
\text { and oil derivative waste in the } \\
\text { soil. They consist in selective } \\
\text { actions by relevant bacterial } \\
\text { strains decomposing toxic } \\
\text { substances [14]. }\end{array}$ \\
\hline $\begin{array}{l}\text { Chemical, } \\
\text { physical, } \\
\text { physico- } \\
\text { chemical }\end{array}$ & $\begin{array}{l}06,07,09, \\
10,11,12, \\
13,16,17, \\
19,20\end{array}$ & $\begin{array}{l}\text { The most commonly applied } \\
\text { chemical methods consist in the } \\
\text { neutralization of acids and } \\
\text { alkalis. It is the precipitation of } \\
\text { sparingly soluble chemical } \\
\text { compounds of heavy metals } \\
\text { included in waste in order to }\end{array}$ \\
\hline
\end{tabular}


Table 6 (cont.)

\begin{tabular}{|l|l|l|}
\hline & & $\begin{array}{l}\text { lower its solubility in water and } \\
\text { processes of immobilization } \\
\text { (sealing in concrete mass, } \\
\text { vitrification). Another method is } \\
\text { de-halogenation of chloro- } \\
\text { organic compounds from used } \\
\text { transformer oils, solvents and } \\
\text { plant protection products. Other } \\
\text { methods are also: distillation, gas } \\
\text { stripping, extraction, adsorption } \\
\text { as well as other physical } \\
\text { processes [10]. }\end{array}$ \\
\hline Storage & $10,17,19$ & $\begin{array}{l}\text { Exceptional way of hazardous } \\
\text { waste disposal is storage [15]. }\end{array}$ \\
\hline
\end{tabular}

\section{Case study - waste management options}

The integrated approach for the environment protection against the negative influence of industrial activity places the emphasis first of all on the prevention, reduction and elimination of contamination. At the same time it is supposed to ensure the rational management of natural resources $[16,17]$. Such approach has to take into account economic aspects too, so the consideration of costs and benefits. Using this kind of measures is not an easy task. It is necessary to combine several indicators and namely - technical and economic and ecological ones [18].

In order to make an analysis, it is worth taking a look at four selected instances of hazardous waste for which the manner of disposal to date was mostly the storage (Table 7).

Table 7. Proposal of alternative proceeding with chosen kinds of hazardous waste.

\begin{tabular}{|l|l|l|}
\hline Waste $^{1}$ & $\begin{array}{l}\text { Current } \\
\text { condition }\end{array}$ & Proposal \\
\hline $010505 \cdot$ & $\begin{array}{l}\text { D5 }(92 \%), \\
\text { D2 (8\%) }\end{array}$ & $\begin{array}{l}\text { In case of waste containing } \\
\text { hydrocarbons methods are } \\
\text { permissible pres05 } \\
\text { thermal processing of waste, } \\
\text { bioremediation and } \\
\text { solidification with use of } \\
\text { pozzolana }\end{array}$ \\
\hline 060403 & $\begin{array}{l}\text { D5 (80\%), } \\
\text { D9 (10\%), }\end{array}$ & $\begin{array}{l}\text { Solid waste containing arsenic } \\
\text { should undergo processes of } \\
\text { solidification, while liquid } \\
\text { Daste containing arsenic } \\
\text { should be subject to processes } \\
\text { of precipitation and then } \\
\text { solidification after dehydration. }\end{array}$ \\
\hline 120118 & D5 (100\%) & $\begin{array}{l}\text { Sludge from treatment of } \\
\text { metals containing oils should } \\
\text { be solidified. }\end{array}$ \\
\hline 150202 & D5 (100\%) & $\begin{array}{l}\text { Waste from 150202 should } \\
\text { undergo thermal degradation. }\end{array}$ \\
\hline
\end{tabular}

${ }^{1}$ - numbers of codes in accordance with the Regulation of the Minister for the Environment as of the $9^{\text {th }}$ of December 2014 concerning the catalogue of waste (Journal of Laws 2014, item 1923) [19]

010505- oil-containing drilling muds and wastes
$060403^{-}$- wastes containing arsenic

120118 - metal sludge (grinding, honing and lapping sludge) containing oil

150202 - absorbents, filter materials (including oil filters not otherwise specified), wiping cloths, protective clothing contaminated by hazardous substances

2 - numbers of codes in accordance with the Act on waste (Journal of Laws 2013, item 21) [20]

D2 - Land treatment (e.g. biodegradation of liquid or sludgy discards in soils, etc.)

D5 - Specially engineered landfill (e.g. placement into lined discrete cells which are capped and isolated from one another and the environment, etc.)

D8 - Biological treatment not specified elsewhere in this Annex which results in final compounds or mixtures which are discarded by means of any of the operations numbered D1 to D12

D9 - Physico-chemical treatment not specified elsewhere in this Annex which results in final compounds or mixtures which are discarded by means of any of the operations numbered D1 to D12 (e.g. evaporation, drying, calcination, etc.)

The main feature which makes the utilization of extractive waste difficult is the high content of water and the consistency of waste related to that (colloidal and sludgy in case of drilling waste and liquid in case of flow-back fluid). Hindrance is also the changeable and hard-to-predict chemical composition of waste (e.g. high variables of contents of heavy metals and salts of some alkaline elements (usually $\mathrm{K}$ and $\mathrm{Na}$ ) in a form of chlorides, sulphates and hydrogen carbonates [21]. Biological treatment methods rely on the natural metabolic processes of living organisms (e.g. bacteria, fungi and higher plants) to destroy contaminants or convert them to a less toxic or less available form. The processes usually involve metabolisation of carbonbearing substrates by organisms to generate energy for growth and reproduction. Bioremediation is commonly more effective for water-soluble contaminants since most biological activity takes place in this phase. The cost of biological treatment is generally lower than other treatment methods and many biological treatment techniques do not give rise to process residues requiring further treatment or disposal. Some of the techniques require large process areas and long time periods to achieve acceptable concentrations [22]. One of methods of recycling of drilling waste is solidification (immobilisation) of output. It is most commonly used in case of betonite drilling fluids [23]. The method consists in adding binding materials in a form of Portland cement, gypsum, limestone, fly ashes, blast furnace slag and hydraulic and puzzolans binder [21]. It causes hydraulic binding of soluble compounds (chlorides, heavy metals, petroleum-derived substances). This also increases physicochemical stability and mechanical resistance of the obtained material $[21,23]$.

The environmental contamination by arsenic is incidental in nature - it is a result of conduct of hightemperature processes on a large scale with the use of organic and non-organic natural resources as reagents and energy factors. Liquid and solid waste containing arsenic is the outcome of those processes. In the vast majority of cases the extraction of arsenic contained in 
the waste is not economically viable because of too low concentration. For the disposal of liquid waste one utilizes precipitation methods consisting in binding removed ions containing arsenic into compounds insoluble in water. Obtained sediments are dehydrated in order to decrease their volume. The solid waste is subject to processes of solidification in a matrix of Portland cement with an addition of calcium, iron compounds and fly ashes [24-30].

Difficulties in complete management of metallurgic waste, especially for metallurgical purposes, arise mainly from the lack of proper economically viable technologies of its treatment for further use (e.g. concentration and dehydration of sludges, de-oiling of scale, removal of harmful elements) [31]. Metallurgic waste is especially difficult to dispose due to high hydration and high content of oils. This is why more and more frequently research is conducted on the possibility of use of the waste as additions for concrete coatings against ionizing radiation. As it arises from the performed examinations [32] the addition of the waste increases mechanical and adsorption properties of concrete coatings.

Materials such as used sorbents, oil filters and textile materials contaminated with hazardous substances should be disposed with use of thermal methods. Remains after the incineration (slag and ash) amount to 20-60 percent by weight and 10-20 percent by volume of the original mass of waste [5].

Each strategy of development of hazardous waste recovery/disposal plant requires taking investment initiatives executed in specific enterprises. One should bear in mind, however, that the primary objective of company operation is generating profits. The development strategy may involve not only modernization and innovative investments, but also ventures regarding the public interest connected with specific legal regulations - as in the described cases which serve the environment protection.

On the basis of data provided in the literature $[6,8$, 33] which includes the structure of costs related to construction of facilities, facility maintenance and costs of treatment of particular waste, discount costs have been calculated - both investment and operating onesfor three installations: hazardous waste combustion plant, hazardous waste solidification plant and bioremediation facility. The aim of analysis was calculating the value of unit cost (PLN/Mg) with the use of dynamic (discount) methods. In this work [34] NPV (Net Present Value) and IRR (Internal Rate of Return) indicators have been calculated. Only those two indicators have been calculated as others are static and rather useless for the analysis of facilities functioning for more than a dozen of years. The calculation was supplemented by the count of an average cost of waste treatment which should be the basis for determining the price. Such cost is defined as a quotient of discounted total costs and a discounted amount of treated waste. Indicators for prices listed in the literature sources have also been compared (Table 8).

The price of disposal of $1 \mathrm{Mg}$ of hazardous waste for the technology of immobilization is 469 PLN. Calculated costs of combustion of $1 \mathrm{Mg}$ of waste are at 1,758 PLN, while the cost of bioremediation of $1 \mathrm{Mg}$ of waste is 310 PLN.

Table 8. Listing of calculated costs of hazardous waste disposal (author's own research based on [9, 22, 34, 35].

\begin{tabular}{|l|c|c|}
\hline Technology & $\begin{array}{c}\text { Calculated } \\
\text { disposal cost, } \\
\text { [PLN/Mg] }\end{array}$ & $\begin{array}{c}\text { Unit costs of disposal } \\
\text { quoted in literature, } \\
\text { [PLN/Mg] }\end{array}$ \\
\hline Immobilization & 469 & $132^{1}-1,220^{2}$ \\
\hline $\begin{array}{l}\text { Incineration of } \\
\text { solid hazardous } \\
\text { waste }\end{array}$ & 1,758 & $\begin{array}{c}150-3,667^{1} \\
3,050^{2} \\
1,000-2,400^{3}\end{array}$ \\
\hline Bioremediation & 310 & $150-3,667^{1}$ \\
$315^{3}$
\end{tabular}

The given values have been calculated from the original data (quoted in USD for the year 2005 ${ }^{1}$ ) with the use of US Dollar Implicit Price Deflators for Gross Domestic Product 19292013. The year 2010 has been adopted as the reference year. The value has been calculated from the original data in USD ${ }^{1}$ and Euro $^{3}$ with the NBP (National Bank of Poland) average exchange rate (year 2010) at $3.0157 \mathrm{PLN} / \mathrm{USD}$ and 4.03 PLN/€.

The given values have been calculated from the original data (stated in PLN for the year $2002^{2}$ ) with the use of GDP Deflator (annual percent) Poland 1991-2016 (The United Nations Industrial Commodity Statistics Database). The year 2010 has been adopted as the reference year.

1 - prices from the year 2005 [35]

2 - prices from the year 2002 [9]

3 - prices from the year 2010 [22]

The calculated values are within the range of actual prices. Economic criteria, although significant, cannot still prevail in deciding about the method of disposal or recovery. The most important is till the proper neutralization of waste. The selected methods do not generate unreasonable costs and therefore they do not pose a threat to the economic development and they reduce significantly the contamination of the environment at the same time.

\section{Summary}

The hazardous waste poses a serious threat to all components of the environment (soil, water, air). This is why the selection of proper process of disposal or recovery (consistent with engineering knowledge) is so important. Due to its properties, the stage of proper selective collection and storage of waste (before the actual disposal/recovery) is very important. Any emission or irregularity may result in serious pollution of both soil and water.

One should ascertain that:

1. The structure of generated waste is a result of industrial specificity of a given state. In all of the European Union UE-28 a total of 95,02 million $\mathrm{Mg}$ of hazardous waste was produced in 2014. Poland is in a group of those countries, which generated the least ( 2 percent) of hazardous waste in 2014. The most of hazardous waste was produced in France (11\%), Bulgaria (13\%) and Germany (23\%).

2. The biggest part of dangerous waste underwent processes of recovery other than energy recovery - 
except backfilling - 79,53\%. Unfortunately, some $13 \%$ of hazardous waste is still deposited.

3. In the classification of technologies of hazardous waste disposal one accepts the rule of grouping waste according to its properties and possibilities of disposal (Table 1). Depending on the chemical composition the waste can be disposed in identical conditions. In Table 2 particular groups of hazardous waste along with applied methods of their disposal are presented.

4. In the work all aspects of dangerous waste management (both environmental, technical and economic), which should be followed while choosing modern techniques of management of hazardous waste, have been discussed.

5. Alternative methods of proceeding with four groups of waste for which the most frequently applied method of disposal is the storage have been proposed (Table 7).

6. Calculated values of prices of waste disposal placed in Table 8 are in a range of actual prices.

7. Proposed changes in the manner of proceeding with waste collected currently on hazardous waste landfills contribute significantly to limiting this practice which is the least favorable to the environment.

The work is financed within the frames of statutory research no 11.11.210.373 at the Faculty of Energy and Fuels, AGH University of Science and Technology.

\section{References}

1. Eurostat (2017) http://ec.europa.eu/eurostat/web/ environment/waste/d atabase

2. J. Pyssa, Gospod. Surowcami Min. 24, 1/1, 113-125 (2008)

3. Cz. Rosik-Dulewska, Fundamentals of Waste Management (Polish Scientific Publishers PWN, Warsaw, 2015) (in Polish)

4. J. Bendkowski, M. Wengierek, Logistics of Waste Logistic Processes in Waste Management (Publisher Politechnika Śląska, Gliwice, 2002) (in Polish)

5. J. Bendkowski, M. Wengierek, Logistics of Waste Facilities for Waste Management (Publisher Politechnika Śląska, Gliwice, 2004) (in Polish)

6. J. Pyssa, Przemysł chemiczny/Chemical industry 89/7, 927-934 (2010)

7. http://www.access.zgwrp.org.pl/materialy/dokument y/PlanyGospodarkiOdpadami/1/kpgo/Rozdzial_3.3.p df

8. Best Available Techniques (BAT) Reference Document for Waste Treatment. Industrial Emissions Directive (2010/75/EU) (Integrated Pollution Prevention and Control). European Union, December 2015

9. Monitor Polski (the Official Journal) no 11, item 159, Resolution no 219 of the Council of Ministers of the $29^{\text {th }}$ of October 2002 on National waste management plan, Warsaw, of the $28^{\text {th }}$ of February 2003

10. M.N. Rao, R. Sultana, S.H. Kota, Solid and Hazardous Waste Management. Science and Technology (Butterworth-Heinemann, 2017) p. 159207.

11. J. Pyssa, IOP Conference Series: Earth and Environmental Science (2017) (to be published)

12. J. Wu, Y. Guo, Ch. Li, H. Qi, J. Cleaner Prod. 149, 49-59 (2017)

13. Regulation of the Minister of Economic Development of the $21^{\text {st }}$ of January 2016 (Journal of Laws 2016, item 108) on requirements concerning the conduct of process of thermal transformation of waste and ways of proceeding with waste resulting from that process

14. T.C. Zhang, R.Y. Surampalli, R.D.Tyagi, S.K. Benerji, Current Developments in Biotechnology and Bioengineering. Solid Waste Management (Elsevier B.V., 2017) p. 311-340

15. I. Pecorini, F. Baldi, D. Bacchi, E.A. Carnevale, A. Corti, Waste Manage. 63, 96-106 (2017)

16. National Hazardous Waste Management Plan 2014 - 2020 (Environmental Protection Agency, Ireland, 2014)

17. Resolution no 88 of the Council of Ministers of the $1^{\text {st }}$ of July 2016 on National waste management plan 2022 (M.P. 2016, item 784)

18. M. Gollinger-Tarajko, Recovery of Waste Technologies and Possibilities (Publisher IGSMiE PAN, Kraków, 2005) p. 14-22.

19. Regulation of the Minister for the Environment as of the $9^{\text {th }}$ of December 2014 concerning the catalogue of waste (Journal of Laws 2014, item 1923)

20. Act on waste (Journal of Laws 2013, item 21) of the $14^{\text {th }}$ of December 2012 (uniform text Journal of Laws 2016, item 1987, 1954)

21. J. Pyssa, E3S Web of Conferences 10, 00076 (2016)

22. Technical and Economic Aspects of developing a National Difficult Waste Facility (NaDWaF) (SKM Enviros, July 2010)

23. T. Steliga, M. Uliasz, Nafta-Gaz, 5, 273-283 (2012)

24. C. Visvanathan, Resour. Conserv. Recycl. 16, 201212 (1996)

25. C. Vandecasteele, V. Dutre, D. Geysen, G. Wauters, Waste Manage. 22/2, 143-146 (2002)

26. T.S. Singh, K.K. Pant Journal of Hazardous Materials, 131/1-3, 29-36 (2006)

27. Ch.D. Johnson, J. Feldmann, D.E. Macphee, Waste Manage. 27, 375-379 (2007)

28. J. Kumpiene, A. Lagerkvist, Ch. Maurice, Waste Manage. 28, 215-225 (2008)

29. I.H. Yoon, D. H. Moon, K.W. Kim, K.Y. Lee, J.H. Lee, M. G. Kim, J. Environ. Manage., 91/11, 2322 2328 (2010)

30. X. Wang, F. Zhang, Z. Nong The Scientific World Journal, 2014, Article ID260504 (2014) 
31. A. Frackowiak, M. Pacholewska J. Buzek, Rudy i Metale Nieżelazne 51/1, 325-332 (2006)

32. M. Alwaeli, Fuel from waste $V$ (Publisher Helion S.A. Gliwice, 2005) p. 391-394 (in Polish)

33. Best Available Techniques (BAT). Reference Document on Waste Incineration. May 2017

34. J. Pyssa Selection of technologies for the disposal of hazardous waste in the aspect of environmental protection on the example of the Matopolska province. Doctoral thesis (Akademia GórniczoHutnicza, Kraków, 2008) p. 1-191.

35. M. G. Puder, J. A. Veil, Offsite Commercial Disposal of Oil and Gas Exploration and Production Waste: Availability, Options and Costs. ANL/EVS/R-06/5. Environmental Science Division, August 2006 